\title{
MIRAR A LUISITA
}

Hugo Manso / fotoestudioluisita@gmail.com

Universidad del Cine. Argentina

Recibido: 9/4/2020 / Aceptado: 12/7/2020

\section{RESUMEN}

En este ensayo Hugo Manso — realizador, guionista y docente- se dedica a poner en palabras sus recuerdos y sus consideraciones sobre la fotógrafa Luisita Escarria y sobre el trabajo de archivo que realiza Sol Miraglia, desde hace más de doce años, en el Foto estudio Luisita. Junto con Miraglia, Manso dirigió la película homónima, en 2018, sobre las hermanas Escarria: Luisa, Graciela y Rosa.

\section{PALABRAS CLAVE}

Foto estudio Luisita; archivo; Hermanas Escarria; Sol Miraglia

\section{LOOK AT LUISITA}

\section{ABSTRACT}

In this essay Hugo Manso — director, screenwriter and teacher — is dedicated to bringing us closer to his memories and thoughts of the photographer Luisita Escarria and the archival work that Sol Miraglia has been doing for more than twelve years with her images in the Foto estudio Luisita.

KEYWORDS

Foto estudio Luisita; Archive; Escarria Sisters; Sol Miraglia 
Luisita abre la puerta y me recibe: «¿Cómo estás tesoro? Porque yo muy bien ahora que te veo». Fijas en las paredes, las estrellas custodian la entrada. «Tomá un caramelito, es de dulce de leche». Un disco comienza a girar y mis recuerdos afloran como si formaran una única melodía que nunca me canso de tararear. Las anécdotas con Amelita Vargas y sus festejantes, los encuentros en Montevideo con Ixs Bahaí. Las tacitas de porcelana, los platos de plástico con las Surtido Bagley.

«Lo que más extraño de Cali es el perfume de flores que hay por las calles». Todo se mezcla y se repite una y otra vez de la manera más natural rebotando en aquel living y en mí. Como la Rumba azul (1994), de Caetano Veloso, que ahora me suena loopeada en la cabeza cuando recuerdo estar hablando sobre ofertas de Coto, documentales de Animal Planet o sobre cómo preparar unas arepas ecuatorianas. Porque así las hacía su madre, que era de Milagros, un pueblo de Ecuador casi en la frontera con Colombia.

\section{A la rumba azul vamos, llega chique-chique-chique-chique.}

La primera vez que cenamos juntxs en nuestra vida, Sol me mostró algo que venía filmando. En la pantalla de la computadora aparecían dos duendes luminosos con tono caribeño que se sentaban a tomar el té con leche. Un plano fijo de cuarenta minutos. Hablaban con Sol —que estaba fuera de cuadro- sobre sus perras, la salud de Mirtha Legrand y acerca de que, en una época, también fueron criadoras de canarios. «Volaban por toda la casa, venía gente para que Luisita les tome fotos y se divertían al ver a los pajaritos yendo y viniendo».

Cuando la conocí a Sol, ella tenía veinticinco años y desde los diecinueve frecuentaba a las hermanas Escarria; de paso las filmaba, sin saber muy bien para qué. Con el paso del tiempo, Sol iba descubriendo de a poco la historia del estudio, las chicas habían sido fotógrafas de las estrellas del teatro revista durante más de tres décadas. Pero no le importó contarme eso al principio, solo hablaba de lo cómoda que se sentía ahí, en ese living donde Luisa y Chela la recibían.

Naturalmente, me enamoré de la mirada de Sol. Fue una consecuencia de amores a primera vista.

Es su canto azul, sensual, con su tique-tique-tique-tique.

Las fotos que Luisa y Chela hicieron de sus mascotas me atrajeron siempre. Siento que en esas imágenes brota el cotidiano de las hermanas. La complicidad del juego y la búsqueda de la belleza a través de la ternura. Gracias a esas fotos pude empezar a definir el lugar desde donde me iba a ubicar para hacer el documental. En ese archivo es donde reencuentro a Luisita como si estuviéramos mirándonos a los ojos.

Mirarnos a los ojos con Luisa. Eso me recuerda cuando ella estaba internada en el hospital de la Unión Obrera Metalúrgica (UOM) de Avellaneda y desde la cama nos contó un sueño que tuvo durante la noche: estaba sola en una iglesia enorme, la cual se encontraba iluminada de una manera que la hacía sentir cómoda y agradecida: «Me sentí en paz, feliz». La médica que la atendió en el hospital era ecuatoriana, casualmente de Milagros, de donde era su mamá.

No hubo más tiempo y se apagó todo. Antes de eso: «Cuiden a Chelita». Vivir es estar y acompañar.

Entiendo lo que representa el archivo de Foto estudio Luisita, no solo lo entiendo, sino que estoy convencido de que es necesario para expandir el tan limitado - en todos los sentidos - territorio de la fotografía argentina. Ese mismo territorio que en su momento fue cancelado para Luisa. No solo por su condición de mujer, sino por sus raíces. Claro, una colombiana 
que no era intelectual ni se juntaba con gente que la conecte con otra gente para conseguir la supuesta bendición de un grupo de iluminadxs que deciden impunemente sobre si esto o aquello es arte o no lo es.

A Luisita nunca le interesaron esas cosas. Es más, ella no se consideraba artista, sino más bien una trabajadora que hacía lo que tenía que hacer. Una trabajadora que amaba su oficio. Mientras los canarios iban y venían por el departamento, cientxs de artistas posaban y charlaban con la mamá de las chicas, disfrutaban de las arepas que Chela preparaba al mismo tiempo que organizaba las luces. En un mundo veloz existía la dulce quietud de ese estudio. ¿Qué es un artista?

Y Luisita siguió haciendo lo suyo, sea retratando a las grandes estrellas del espectáculo o a las tantas bandas de cumbia que se asomaban tímidamente a la ciudad para probar suerte. Así pasaron los años y una vida después apareció en el living una chica de diecinueve años que empezó a visitarla a menudo y a enamorarse de aquel universo. Esa galaxia de animales, flores y personas en color o blanco y negro que comienza y termina en Chela. Si Luisita trabajaba con calidez, su hermana lo hacía desde una especie de discreción invisible, etérea. Juntas crearon ese mundo, acompañándose una a la otra y potenciando el magnetismo que, por ejemplo, me atrapa al mirar una foto de Gigi — su perra salchicha que las acompañó durante más de diecisiete años- con una gorrita en la cabeza. O los tres cachorros cocker en una canasta, asomando con sus orejas largas [Figura 1].

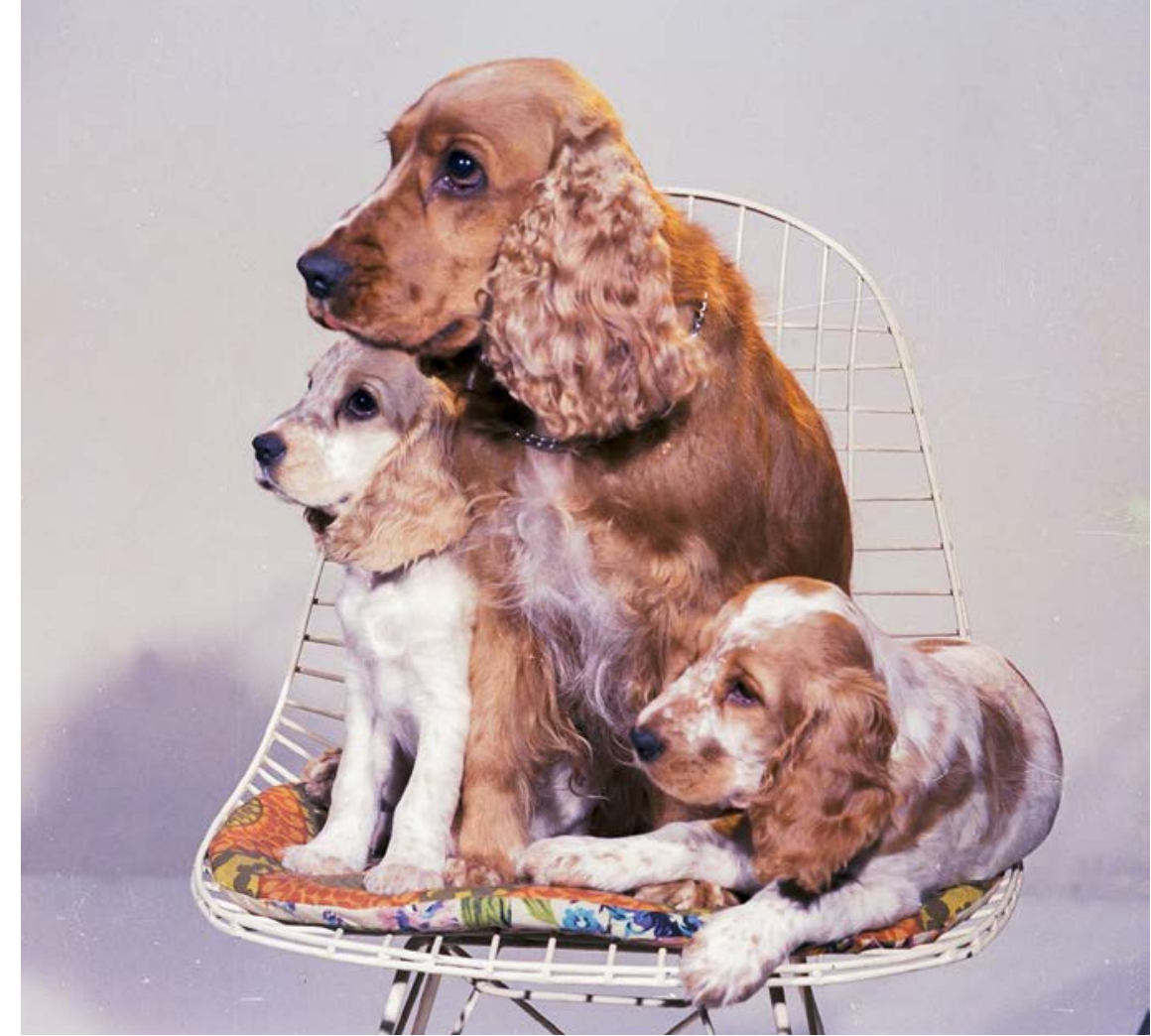

Figura 1. Mascotas (s. f.), Fotografía. Foto estudio Luisita

¿Qué es un artista? El que busca la belleza de las cosas. Ellas jugando con la cámara y los focos de luz, siempre con la madre al lado. Casi todo sucedió en ese living, el mismo del loop de la Rumba azul.

Dulce es mi cantar. Oh, rumba azul.

A las hermanas les parecía una pérdida de tiempo la idea de andar revolviendo su archivo, no le encontraban nada interesante. De hecho, lo único que Luisita mostraba con orgullo era un gastado álbum de fotos con retratos de famosos. Cada una de esas imágenes llevaba una dedicatoria con su nombre, que leía con esa mezcla de timidez y candor típica de ella. Era su tesoro, su manera de recordar y de mostrar lo que había hecho. 
No hay más vueltas que esto.

Un almanaque del estudio con estrellas hechas de strass, una taza con té de manzanilla y miel, la foto de un cachorro que me mira a los ojos [Figura 2].
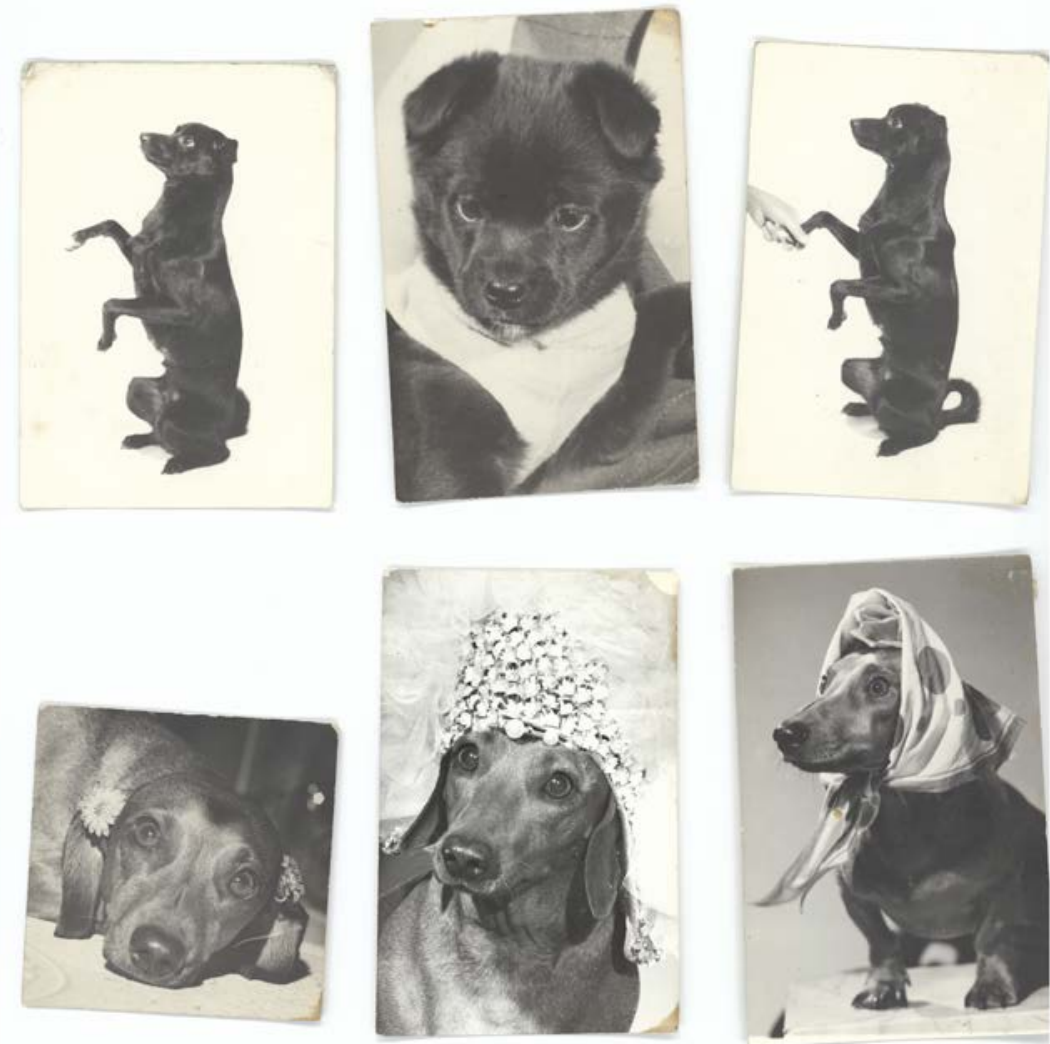

Es un triunfo que el archivo de Luisita comience a circular y que gracias al enorme trabajo de Sol cualquier persona pueda conocerlo. Un triunfo de aquellxs que fueron ignoradxs, discriminadxs, invisibilizadxs. Es un triunfo del amor, en el sentido más naif que se le quiera dar, no me importa. Porque llevo tatuado con orgullo el bolero y la novela de la tarde, la fresita, los sanguchitos de miga con jamón y ananá, las perras roncando y una mano de Luisita que me acaricia la mejilla: «Volvé pronto corazón, que ya te extraño».

¿Qué es un artista? Ella es una artista. Es el amor directo, de mirada a mirada. La belleza de las cosas. Tuvimos la suerte de conocerla y compartir momentos tan hermosos como lo puede ser una pastafrola un domingo en el living mientras tomamos té y vuelve a empezar el tiempo.

Ya llegó el amor. ;Ay, ay, ay, ay!

Gracias a Sol por el regalo de su compañía y por haberme hecho parte de este viaje tan bello. 